\title{
DIVERSITY, ANTIMICROBIAL CHARACTERIZATION AND BIOFILM FORMATION OF ENTEROCOCCI ISOLATED FROM AQUACULTURE AND SLAUGHTERHOUSE SOURCES IN BENIN CITY, NIGERIA
}

\author{
${ }^{1,2 *}$ Igbinosa, E. O., ${ }^{1,3}$ Beshiru, A. and ${ }^{4}$ Odjadjare, E.E.O. \\ ${ }^{1}$ Applied Microbial Processes \& Environmental Health Research Group (AMPEHREG), Department of Microbiology, \\ Faculty of Life Sciences, University of Benin, Private Mail Bag 1154 Benin City 300001, Nigeria. \\ ${ }^{2}$ Sustainable Development Office, University of Benin, Private Mail Bag 1154, Benin City 300283, Nigeria. \\ ${ }^{3}$ Department of Microbiology, College of Natural and Applied Sciences, Western Delta University, Private Mail Bag 10 \\ Oghara 331101, Delta State, Nigeria. \\ ${ }^{4}$ Environmental, Public Health and Bioresource Microbiology Research Group (EPHBIOMREG), Department of \\ Biological Sciences, Benson Idahosa University, Private Mail Bag 1100, Benin City 300001, Nigeria. \\ *Corresponding author's e-mail: eigbinosa@gmail.com \\ (Received: $9^{\text {th }}$ January, 2020; Accepted: $7^{\text {th }}$ August, 2020)
}

\section{ABSTRACT}

\begin{abstract}
The present study was designed to characterize Enterococci isolates obtained from water samples at aquaculture and slaughterhouse facilities in Benin City, Nigeria. A total of 144 water samples were collected from aquaculture and slaughterhouse facilities. All samples were analyzed using classical microbiological and molecular-based methods. Enterococci were identified using specific primer sets (genus and species specific primers) and are as follows: E. faecalis 36 (25.5\%); E. faecium 39 (27.7\%); E. durans 19 (13.4\%); E. casseliflavus 13 (9.2\%); E. birae 14 $(9.9 \%)$ and other Enterococcus species 20 (14.2\%). The resistance profile of the bacterial strains to antibiotics was as follows: [tetracycline $(n=67,47 \%)$ ]; [vancomycin $(n=74,52 \%)$; [erythromycin $(n=91,64 \%)$ ] and [penicillin $(\mathrm{n}=141,100 \%)]$. Enterococci virulence genes detected include: [ge $\mathbb{E}(\mathrm{n}=120,85.1 \%)] ;[\mathrm{cy} / \mathrm{A}(\mathrm{n}=52,36.9 \%)] ;[\mathrm{by} /$ $(n=96,68.1 \%)] ;[\operatorname{esp}(n=135,95.8 \%)] ;[$ ace $(n=127,90.1 \%)]$ and $[\operatorname{agg} n=118,83.7 \%)]$. Antibiotic-resistant gene detected from the phenotypic resistant isolates were 55/74 (74.3\%) vanA; $61 / 67$ (91.1\%) tetC; 122/141 (86.5\%) blapse1 and 62/91 (68.1\%) ermA. Antibiotic-resistant coupled with biofilm formation potential of Enterococcus species include penicillin+biofilm $116(82.3 \%)$; erythromycin+biofilm 85 (60.3\%); and vancomycin+biofilm 74 $(52.3 \%)$. Findings from this study reveal that strains with the ability of forming biofilms have enhanced antimicrobial resistance. Continuous monitoring of slaughterhouses and aquaculture facilities is necessary to guarantee food safety.
\end{abstract}

Key Words: Aquaculture, Biofilm, Enterococcus, Environments, Resistance, Slaughterhouse

\section{INTRODUCTION}

Enterococci have the capacity to thrive in harsh environmental conditions and enables them to proliferate from low-density commensals to a dominant population of microbiota; thus forming a predisposition for pathogenesis (Staley et al., 2014). Regardless of being a predominant adherent of the human intestinal flora, they are no longer classified as "Generally Recognized As Safe" (GRAS) organisms (Rathnayake et al., 2012); as some of its members have been reported as major causes of hepatobiliary sepsis, urinary tract infections, surgical wound infections, endocarditis, neonatal sepsis, bacteraemia and other nosocomial infections (Elhani et al., 2014). Enterococci, being a carrier of a multiplicity of mobile genetic elements are responsible for diverse host range gene acquisition or gene dissemination which jointly makes them resist multiple antibiotics (Beshiru et al., 2017).
Enterococci are efficient at being resistant to antibiotics, revealing a variety of pathway for intrinsic and acquired resistance. The organisms have been reported to have incredible genome plasticity with a capacity to utilize transposons, plasmids and insertion sequences to proficiently acquire and spread mobile resistance determinants, and consequently expediting the spread of resistance elements (Cattoir and Leclercq, 2013). Antimicrobial resistance is a global phenomenon intertwined with increased illness and death (Frieri et al., 2017). Multidrugresistance in Gram-positive bacteria has led to difficulty treating infections associated with the application of commonly used antibiotics. The significant upsurge in emerging antibiotics resistance across the globe, coupled with dilapidating infection control infrastructure, has resulted in the easy spread of antibiotic-resistant bacteria to other environments and patients 
(Chajecka-Wierzchowska et al., 2016). Increased antibiotic resistance encountered in clinical bacterial pathogens, commensals, bacteria strains of environmental origin, bacteriophages and mobile genetic elements, act as a reservoir of antibiotic resistance genes (ARGs) through which bacterial pathogens can acquire and disseminate resistance via horizontal gene transfer (HGT) (von Wintersdorff et al., 2016).

Traditionally, $90 \%$ of enterococcal infections originate from E. faecalis with just 10\% attributed to E. faecium. However, the frequency of E. faecium has over the years increased to 40\% (Daniel et al., 2015). Other species of enterococci, such as $E$. casseliflavus, E. avium, E. cecorum, E. durans, E. dispar, E. gallinarum, E. malodoratus, E. hirae, E. mundtii, E. raffinosus, E. pseudoavium, E. saccharolyticus, E. solitarius and E. seriolicida, are primarily found in the gastrointestinal tracts of several animals but are rarely recovered from human infections (Daniel $e t$ al., 2015).

Studies relating to the spread of enterococci from food-producing animals to humans have concentrated on disease-causing agents that pose a threat to human health (Marshall and Levy, 2011). Due to the importance of Enterococcus spp. to the farming industry, food security and public health, additional information on the transmission and genetics of antibiotic-resistant enterococci are imperative. Regulations and legislation to manage the use and supply of antimicrobials are very deficient in developing countries (FAO, 2012). The occurrence of multiple drug-resistant (MDR) pathogenic enterococci has increased rapidly (Kang and Song, 2013).

Slaughterhouses are facilities designed and licensed for receiving, holding, slaughtering, inspecting meat from animals and meat products before releasing to the public. Aquaculture environs are also regarded as facilities where fish are nurtured from fingerlings to maturation. The discharge of wastewater especially from aquaculture and slaughterhouses into the environment (water and soil) has increased tremendously due to the persistent demand for meat and fish production to meet the growing need of consumers. The meat and fish processing industry produce a lot of wastewater due to slaughtering of animals, change of water in fish ponds, cleaning of slaughterhouse facilities etc.

In this study, we evaluated the effluent quality of aquaculture and slaughterhouse with regards to the presence of antibiotic resistance enterococci, antibiotic resistance genes (ARGs), and biofilmforming enterococci. The findings of this study will be vital for improving suitable effluent management interventions. This will help to advance the ideals of the United Nations Sustainable Development Goal 3 (good health and well-being) and Goal 6 (clean water and sanitation) framework in developing countries such as Nigeria.

\section{MATERIALS AND METHODS Sample Collection}

A total of 144 samples comprising 72 samples each from aquaculture and slaughterhouse water sources in Benin City Nigeria, were collected using sterile plastic containers between the months of April and November 2017. The specific locations and names of the slaughterhouse and aquaculture environments were withheld as part of the consent by the respective slaughterhouse and aquaculture heads prior to sampling. During sampling from both environments, the water samples were used to rinse the plastic containers three times before collection. Samples include the water source (borehole to storage tank), the point of usage (fish pond and slaughter site), and point of discharge (drains and other open discharge points). The samples were transported in cooling boxes containing ice packs to the Applied Microbial Processes \& Environmental Health Research Group (AMPEHREG) Laboratory for analysis within $4 \mathrm{~h}$ of sample collection.

\section{Isolation of Enterococcus species from the Samples}

Samples from the point of discharge and point of usage were serially diluted $\left(10^{1}-10^{8}\right)$. From the diluents, an aliquot of $100 \mu \mathrm{l}$ was spread-plated on bile aesculin azide (BAA) agar (Merck, Germany) and nutrient agar (Lab M, United Kingdom), while the same aliquot was also spread-plated directly from the source water samples without dilution. All plates were incubated for $18-24 \mathrm{~h}$ at $37^{\circ} \mathrm{C}$. Colonies on both BAA agar and nutrient agar were enumerated and expressed in colony-forming unit per millilitre $(\mathrm{cfu} / \mathrm{ml})$. Thereafter, an average of 
two to three black hallow colonies from BAA agar was sub-cultured on fresh BAA agar and incubated for another $18-24 \mathrm{~h}$ at $37^{\circ} \mathrm{C}$. Isolates were then purified on nutrient agar for another 18$24 \mathrm{~h}$ at $37^{\circ} \mathrm{C}$. Purified isolates were stored on tryptone soy broth (Merck, Darmstadt, Germany) with $30 \%$ glycerol at $-20{ }^{\circ} \mathrm{C}$ until needed for further analysis.

\section{Identification of the Enterococcus species}

All Gram-positive cocci, oxidase- negative (using oxidase strip), catalase-negative, black hallow colonies on BAA agar were subjected to biochemical characterization using Analytical Profile Index (API) 20E (BioMerieux, Marcyl'Étoile, France) following the manufacturer's instruction. Enterococcus faecium (ATCC 19434) was used as positive control strain; while Staphylococcus aureus (ATCC 12600) was used as a negative control. The API strips were critically studied and identities of the isolates secured using API lab plus software (BioMerieux, Marcy l'Etoile, France).

\section{DNA Extraction and Molecular Screening of Enterococcus Identity}

The DNA extraction was carried out using the heat-treated method. Polymerase chain reaction (PCR) using genus-specific and species-specific primers and PCR conditions previously described were used in the identification of the Enterococcus species (Igbinosa and Beshiru, 2019). The Peltierbased Thermal Cycler (MG96p/Y, Zhejiang China) was used in the amplification process. Electrophoresis of the PCR amplicons was performed with $1.0 \%$ agarose gel (CLS-AG100, Warwickshire, United Kingdom) in 0.5 $\times$ TAE buffer (40 mM Tris-HCl, pH 8.5, 1 mM EDTA, 20 $\mathrm{mM}$ sodium acetate) and allowed to run for 55 mins at $100 \mathrm{~V}$. The gels were visualized under a UV transilluminator (EBOX VX5, Vilber Lourmat, France).

\section{Antimicrobial Susceptibility Profile of the Enterococci Isolates}

Enterococcus species were further subjected to antimicrobial susceptibility screening using the disc diffusion method (Kirby-Bauer). Twelve antibiotics were used in this study belonging to nine (9) groups of antimicrobials. They include: Glycopeptide (vancomycin $30 \mu \mathrm{g}$ ), Tetracyclines (tetracycline $30 \mu \mathrm{g}$ ), Fluoroquinolone (ciprofloxacin $50 \mu \mathrm{g}$ ), Carbapenems (meropenem $10 \mu \mathrm{g}$, imipenem $10 \mu \mathrm{g}$ ), Lincosamides (clindamycin $2 \mu \mathrm{g}$ ), Aminoglycosides (kanamycin $30 \mu \mathrm{g}$, streptomycin $10 \mu \mathrm{g})$, Macrolides (erythromycin $15 \mu \mathrm{g}$ ), Phenicols (chloramphenicol $30 \mu \mathrm{g}$ ), and Penicillin (penicillin $\mathrm{G} 10 \mu \mathrm{g}$, and piperacillin $100 \mu \mathrm{g}$ ). Purified colonies were re-suspended on normal saline to obtain 0.5 McFarland turbidity standards. Using a sterile swab dipped in the suspension and the excess liquid removed by pressing against the wall inside the test tubes; the entire surface of Mueller Hinton agar plates (Merck Germany) was inoculated with the test isolates. The antibiotics disc were aseptically impregnated equidistance from each other with an average of 6 antibiotics disc per plate. The plates were allowed to stand for $15 \mathrm{~min}$ before incubation at $37^{\circ} \mathrm{C}$ for $18-24 \mathrm{~h}$. Zones of inhibition were measured and interpreted using breakpoints from the Clinical and Laboratory Standard Institute (2017).

\section{Phenotypic Virulence}

The phenotypic virulence profile of the isolates was determined as described by Beshiru and Igbinosa (2018). Colonies cultivated on tryptone soy agar (TSA) (Merck, Darmstadt, Germany) were re-suspended in $20 \mathrm{ml}$ of tryptone soy broth (TSB). The turbidity of this suspension was adjusted to $10^{6}$ cells $/ \mathrm{ml}$ using the McFarland standard. Haemolytic activity was determined on a sheep blood agar plate. Lipase activity was elucidated on TSA. Gelatinase production was determined on gelatin medium. DNA degrading activity ascertained on DNase agar plates. The presence of surface-layer (Slayer) was assessed by streaking cultures on TSA plates, enhanced with $0.1 \mathrm{mg} / \mathrm{ml}$ Coomassie brilliant blue R 250 (Merck, Darmstadt Germany). All experiments were performed in triplicates.

\section{Characterization of the Biofilm}

Biofilm formation for Enterococcus species was quantitatively assessed using the microtitre plate method. Ninety-six (96) wells microtiter plates were dispensed with $200 \mu$ l of nutrient broth (Lab M, Lancashire, United Kingdom) and thereafter inoculated with $20 \mu \mathrm{l}$ of enterococci isolates cultivated overnight and re-standardized to 0.5 McFarland turbidity standards and incubated 
overnight for 18-24 h. Constituents of respective wells were removed and plates rinsed with sterile phosphate-buffered saline (PBS) and allowed to air dry and thereafter stained with $200 \mu \mathrm{l}$ of $1 \%$ crystal violet for $30 \mathrm{~min}$. Respective wells were rinsed with de-ionised water to remove the crystal violet and allowed to dry at $28 \pm 2{ }^{\circ} \mathrm{C}$. Crystal violet dye bound to adherent cells was made soluble via $150 \mu \mathrm{l}$ of absolute ethanol. The optical densities (OD) of the plates were determined at a wavelength of $570 \mathrm{~nm}$ with the aid of a Microplate reader (Synergy MxBiotekR USA). Mean OD of each triplicate result was calculated along with negative and positive controls. Isolates were grouped as strong $(\mathrm{ODi}>0.12)$, moderate $(\mathrm{ODi}=$ $0.1<0.12$ ), weak (ODc $<\mathrm{ODi}<0.1)$ and nonbiofilm producer $(\mathrm{ODi}<\mathrm{ODc})$ in accordance with the modified methods of Igbinosa and Beshiru, (2019).

PCR screening of Enterococcus species for Antibiotic Resistance and Virulence Genes Enterococcus species confirmed using genus and species-specific primers in this study were further screened for their capacity to harbour antimicrobial resistance and virulence genes. The various virulence signatures screened included $g e l \mathrm{E}, c y l \mathrm{~A}, a g g, e s p$, ace and byl genes (Igbinosa and
Beshiru, 2019); while the antibiotic resistance genes screened included the $\operatorname{van} \mathrm{A}, \operatorname{van} \mathrm{B}, \operatorname{van} \mathrm{C} 21 / 2$, tet $\mathrm{A}$, tet $\mathrm{B}$, tet $\mathrm{C}$ gene, erm $\mathrm{A}$, erm $\mathrm{B}$, erm $\mathrm{C}$, bla TEM $_{\text {gene }}$ and blapse1 using specific primers and PCR conditions (Igbinosa and Beshiru, 2019).

\section{Statistical Analysis}

Statistical analysis was carried out on the data using the Statistical Package (SPSS) version 21.0 and Microsoft Excel 2013. Mean values were expressed in mean and standard deviation using descriptive statistics. Correlation analysis was carried out to determine the effect of the phenotypic virulence variable on similar genotypic virulence variable. P-values less than $0.05(p<0.05)$ were considered statistically significant.

\section{RESULTS}

\section{The Mean Population Cell Density}

The mean heterotrophic bacteria count from the aquaculture point of discharge was $4.1 \pm 0.02$ $\times 10^{9} \mathrm{cfu} / \mathrm{ml}$ while that of the slaughterhouse was $1.1 \pm 0.51 \times 10^{10} \mathrm{cfu} / \mathrm{ml}$ (Table 1$)$. The mean enterococci count from the aquaculture point of discharge was $3.9 \pm 0.10 \times 10^{4} \mathrm{cfu} / \mathrm{ml}$ while that of the slaughterhouse was $2.1 \pm 0.02 \times 10^{5} \mathrm{cfu} / \mathrm{ml}$.

Table 1: The Mean Population Cell Density of Heterotrophic Bacteria and Enterococci Isolates from Aquaculture and Slaughterhouse Environments

\begin{tabular}{|c|c|c|c|c|c|c|c|}
\hline \multirow{2}{*}{$\begin{array}{c}\text { Sampling } \\
\text { point }\end{array}$} & \multirow[b]{2}{*}{$\begin{array}{c}\text { Target } \\
\text { bacteria }\end{array}$} & \multicolumn{3}{|c|}{ Aquaculture environment } & \multicolumn{3}{|c|}{ Slaughterhouse environment } \\
\hline & & $\begin{array}{c}\text { Minimum } \\
(\mathrm{cfu} / \mathrm{ml})\end{array}$ & $\begin{array}{c}\text { Maximum } \\
(\mathrm{cfu} / \mathrm{ml})\end{array}$ & $\begin{array}{c}\text { Mean } \pm \text { SD } \\
(\mathrm{cfu} / \mathrm{ml})\end{array}$ & $\begin{array}{c}\text { Minimum } \\
(\mathrm{cfu} / \mathrm{ml})\end{array}$ & $\begin{array}{c}\text { Maximum } \\
(\mathrm{cfu} / \mathrm{ml})\end{array}$ & $\begin{array}{c}\text { Mean } \pm \text { SD } \\
(\mathrm{cfu} / \mathrm{ml})\end{array}$ \\
\hline \multirow[t]{2}{*}{$\begin{array}{l}\text { Water } \\
\text { source }\end{array}$} & $\begin{array}{l}\text { Heterotrophic } \\
\text { bacteria count }\end{array}$ & $2 \times 10^{0}$ & $2.1 \times 10^{1}$ & $1.2 \pm 0.10 \times 10^{1}$ & $3.0 \times 10^{0}$ & $1.9 \times 10^{1}$ & $1.0 \pm 0.05 \times 10^{1}$ \\
\hline & $\begin{array}{l}\text { Enterococci } \\
\text { count }\end{array}$ & $0 \times 10^{0}$ & $3.0 \times 10^{0}$ & $2.0 \pm 0.01 \times 10^{0}$ & $0 \times 10^{0}$ & $5.0 \times 10^{0}$ & $2.2 \pm 0.01 \times 10^{0}$ \\
\hline \multirow[t]{2}{*}{$\begin{array}{l}\text { Point of } \\
\text { usage }\end{array}$} & $\begin{array}{l}\text { Heterotrophic } \\
\text { bacteria count }\end{array}$ & $1.5 \times 10^{5}$ & $2.3 \times 10^{7}$ & $2.1 \pm 0.01 \times 10^{6}$ & $6.6 \times 10^{6}$ & $4.2 \times 10^{8}$ & $3.8 \pm 0.00 \times 10^{7}$ \\
\hline & $\begin{array}{l}\text { Enterococci } \\
\text { count }\end{array}$ & $1.9 \times 10^{2}$ & $1.0 \times 10^{3}$ & $1.7 \pm 0.03 \times 10^{2}$ & $1.9 \times 10^{3}$ & $1.0 \times 10^{5}$ & $4.5 \pm 0.03 \times 10^{4}$ \\
\hline \multirow[t]{2}{*}{$\begin{array}{l}\text { Point of } \\
\text { discharge }\end{array}$} & $\begin{array}{l}\text { Heterotrophic } \\
\text { bacteria count }\end{array}$ & $6.2 \times 10^{8}$ & $2.7 \times 10^{10}$ & $4.1 \pm 0.02 \times 10^{9}$ & $3.5 \times 10^{8}$ & $2.5 \times 10^{11}$ & $1.1 \pm 0.51 \times 10^{10}$ \\
\hline & $\begin{array}{c}\text { Enterococci } \\
\text { count }\end{array}$ & $3.0 \times 10^{3}$ & $2.8 \times 10^{5}$ & $3.9 \pm 0.10 \times 10^{4}$ & $6.5 \times 10^{3}$ & $2.2 \times 10^{6}$ & $2.1 \pm 0.02 \times 10^{5}$ \\
\hline
\end{tabular}

Distribution of Enterococcus species

The aquaculture environments: 9/67 (13.4\%) enterococci were recovered from the water source, $27 / 67(40.2 \%)$ from the point of usage and $31 / 67(46 \%)$ from the point of discharge.
From the slaughterhouse environments, $11 / 74$ $(14.8 \%)$ enterococci were recovered from the water source, $24 / 74(32.4 \%)$ from the point of usage and $39 / 74(52.7 \%)$ from the point of discharge (Table 2). Overall, E. faecalis 36/141 
(25.5\%), E. faecium 39/141 (27.7\%), E. durans 19/141 (13.4\%), E. casseliflavus $13 / 141$ (9.2\%), E. birae 14/141 (9.9\%), and other Enterococcus species
20/141 (14.2\%) were recovered from both aquaculture and slaughterhouse environments using genus and species-specific primers (Table 2).

Table 2: Distribution of Enterococcus species in Aquaculture and Slaughterhouse Environments

\begin{tabular}{|c|c|c|c|c|c|c|c|}
\hline \multirow{2}{*}{$\begin{array}{r}\text { Enterococcus } \\
\text { species }\end{array}$} & \multicolumn{3}{|c|}{$\begin{array}{l}\text { Aquaculture environment } \\
\qquad n=67\end{array}$} & \multicolumn{3}{|c|}{$\begin{array}{l}\text { Slaughterhouse environment } \\
n=74\end{array}$} & \multirow[t]{2}{*}{$\begin{array}{l}\text { Total } \\
n=141\end{array}$} \\
\hline & $\begin{array}{c}\text { Water } \\
\text { source } n=9\end{array}$ & $\begin{array}{c}\text { Point of } \\
\text { usage } n=27\end{array}$ & $\begin{array}{c}\text { Point of } \\
\text { discharge } n=31\end{array}$ & $\begin{array}{c}\text { Water } \\
\text { source } n=11\end{array}$ & $\begin{array}{c}\text { Point of } \\
\text { usage } n=24\end{array}$ & $\begin{array}{c}\text { Point of discharge } \\
n=39\end{array}$ & \\
\hline E. faecalis & $1(11.1)$ & $7(25.9)$ & $13(41.9)$ & $0(0)$ & $5(20.8)$ & $10(25.6)$ & $36(25.5)$ \\
\hline E. faecium & $3(33.3)$ & $12(44.4)$ & $8(25.8)$ & $2(18.2)$ & $6(25)$ & $8(20.5)$ & $39(27.7)$ \\
\hline E. durans & 1 (11.1) & $5(18.5)$ & $4(12.9)$ & $1(9.1)$ & $4(16.7)$ & $4(10.3)$ & $19(13.4)$ \\
\hline E. casseliflavus & $1(11.1)$ & $0(0)$ & $5(16.1)$ & $1(9.1)$ & $2(8.3)$ & $4(10.3)$ & $13(9.2)$ \\
\hline E. birae & $0(0)$ & $1(3.7)$ & $0(0)$ & $2(18.2)$ & $5(20.8)$ & $6(15.4)$ & $14(9.9)$ \\
\hline $\begin{array}{l}\text { Other Enterococcus } \\
\text { species }\end{array}$ & $3(33.3)$ & $2(7.4)$ & $1(3.2)$ & $5(45.4)$ & $2(8.3)$ & $7(17.9)$ & $20(14.2)$ \\
\hline
\end{tabular}

Antibiotics resistance profile of the Enterococcus species

The results of resistant profile of Enterococcus species in table 3 in this study include vancomycin $74(52 \%)$, tetracycline $67(47 \%)$, clindamycin 131 (93\%), streptomycin 104 (73\%), chloramphenicol $141(100 \%)$ and penicillin G 141 (100\%). It was observed that some strains of E. faecalis $8 / 36$ (22\%), E. faecium $7 / 39$ (18\%), E. durans 1/19 (5\%),
E. casseliflavus 2/13 (15\%), E. birae 1/14 (7\%) and other Enterococcus species $2 / 20$ (10\%) were resistant to all the antibiotics used in this study (Table 4). More so, E. faecalis 34/36 (94\%), E. faecium 35/39 (89\%), E. durans 17/19 (89\%), E. casseliflavus 13/13 (100\%), E. birae 12/14 (85\%) and other Enterococcus species 17/20 (85\%) were resistant to $\mathrm{CLI}^{\mathrm{R}}, \mathrm{CHL}^{\mathrm{R}}, \mathrm{PEN}^{\mathrm{R}}$ (Table 4). 


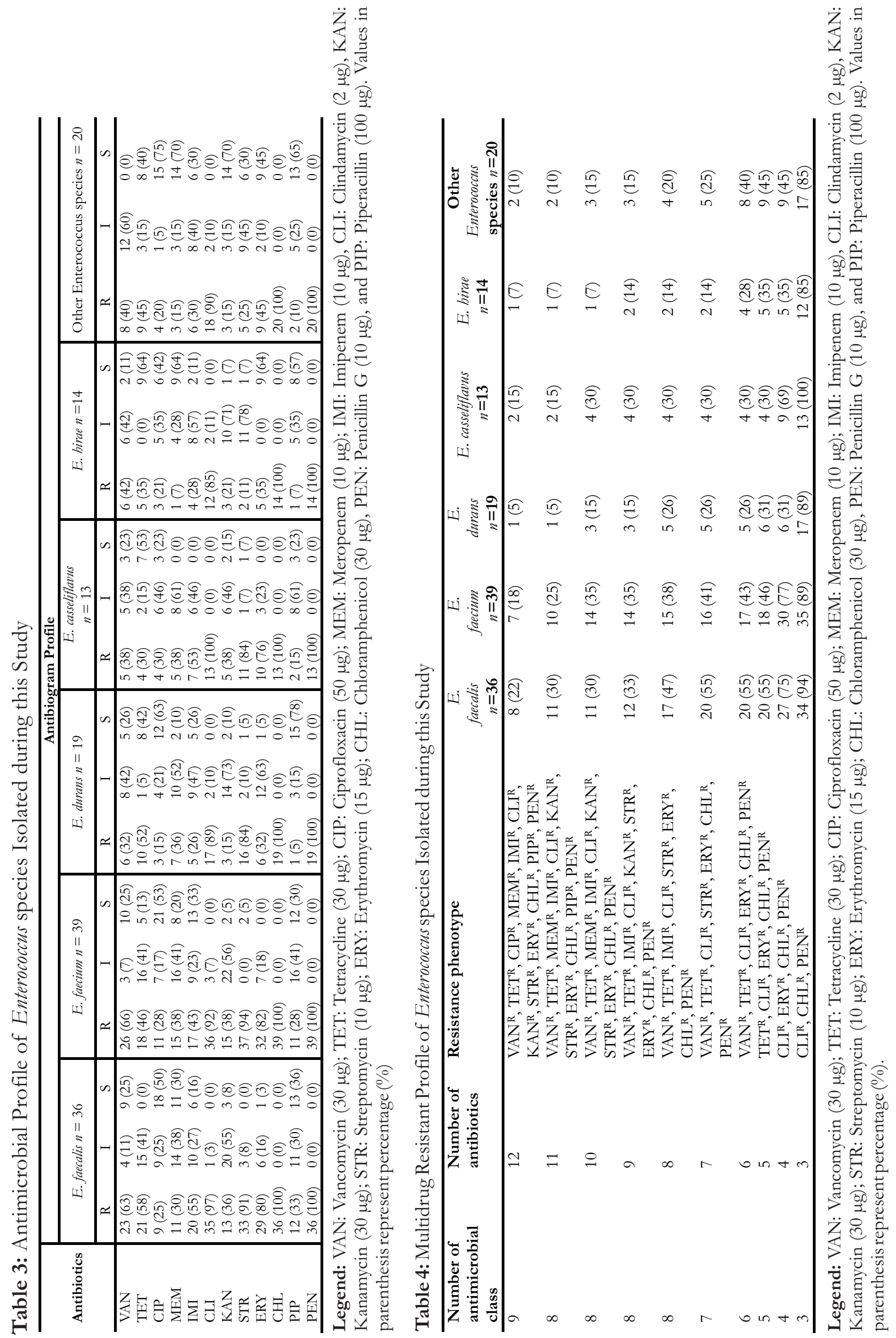


Distribution of Phenotypic Virulence factors in the Enterococcus species

The distribution of virulence factors in the Enterococcus species revealed gelatinase activity: [E. faecalis 33 (91.7\%), E. faecium 38 (97.4\%), E. durans $16(84.2 \%)$, E. casseliflavus $12(92.3 \%)$, E. hirae 7 (50\%) and other Enterococcus species 16 (80\%)]; beta-haemolysis [E. faecalis 16 (44.4\%), E. faecium
$20(51.3 \%)$, E. durans 5 (26.3\%), E. casseliflavus 8 $(61.5 \%)$, E. hirae $5(35.7 \%)$ and other Enterococcus species $4(20 \%)$ ]; and S-layer formation (all Enterococcus species 141 (100\%). Beta-haemolysis occurred in $58(41.1 \%)$ isolates while gelatinase activity occurred in $122(86.5 \%)$ of the enterococci isolates. None of the isolates showed DNA degrading activity (Figure 1).

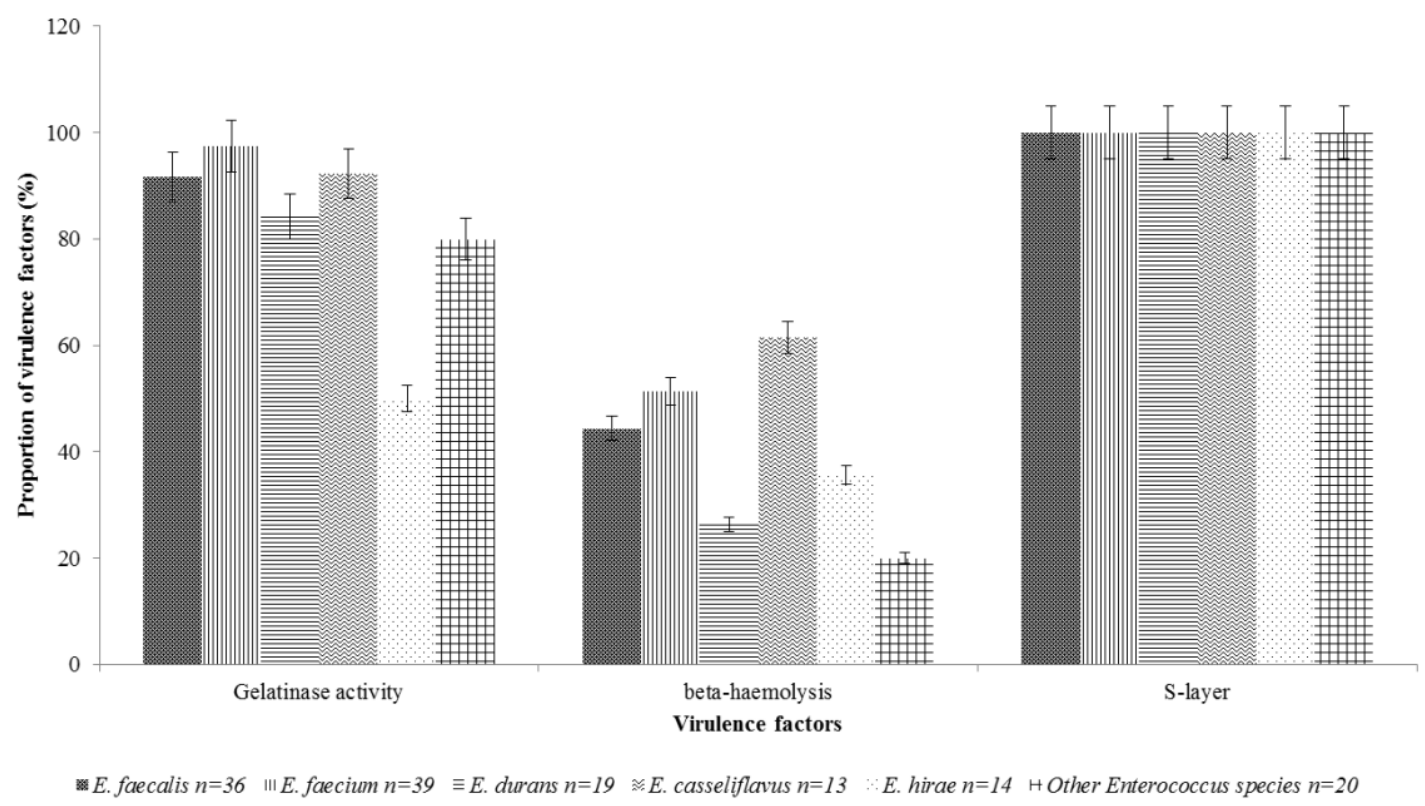

Figure 1: Distribution of Virulence Factors in the Enterococcus species

Distribution of Antibiotic Resistance, Virulence genes and Biofilm Formation

The distribution of antibiotic resistance genes in the Enterococcus species revealed the presence of van $\mathrm{A} 55 / 74(74.3 \%)$, van $\mathrm{B} 50 / 74(67.6 \%)$, van $\mathrm{C}$ 21/2 4/74 (5.4\%), tetA 50/67 (74.6\%), tetC 61/67 (91.1\%), bla (86.5\%), ermA 62/91 (68.1\%), ermB 55/91 (60.4\%), and erm C 5/91 (5.5\%) (Table 5).

The distribution of virulence genes in the Enterococcus species as shown in table 6 revealed the presence of $g e \mathbb{E} 120$ (85.1\%), cylA 52 (36.9\%), byl 96 (68.1\%), esp 135 (95.8\%), ace 127 (90.1\%) and $\operatorname{agg} 118(83.7 \%)$. All enterococci isolates (with the exemption of five strains of Enterococcus hirae) that genetically harboured the gelE phenotype produced gelatinase activity (Compare figure 1 and table 6). Likewise, all enterococci isolate (with the exemption of five strains of other Enterococcus species) that harboured the $c y / A$ gene, phenotype expressed beta-lactamase activity (Compare figure 1 and table 6). Furthermore, all enterococci isolate with the esp gene expressed S-layer production phenotypically (Compare figure 1 and table 6). A significantly positive correlation exists between the beta-haemolytic activity of the Enterococcus species and cylA gene detected in this study $(p<0.05)$. Likewise, a significant positive correlation was observed in this study between Slayer, ace, esp and gelE genes $(p<0.05)$. 


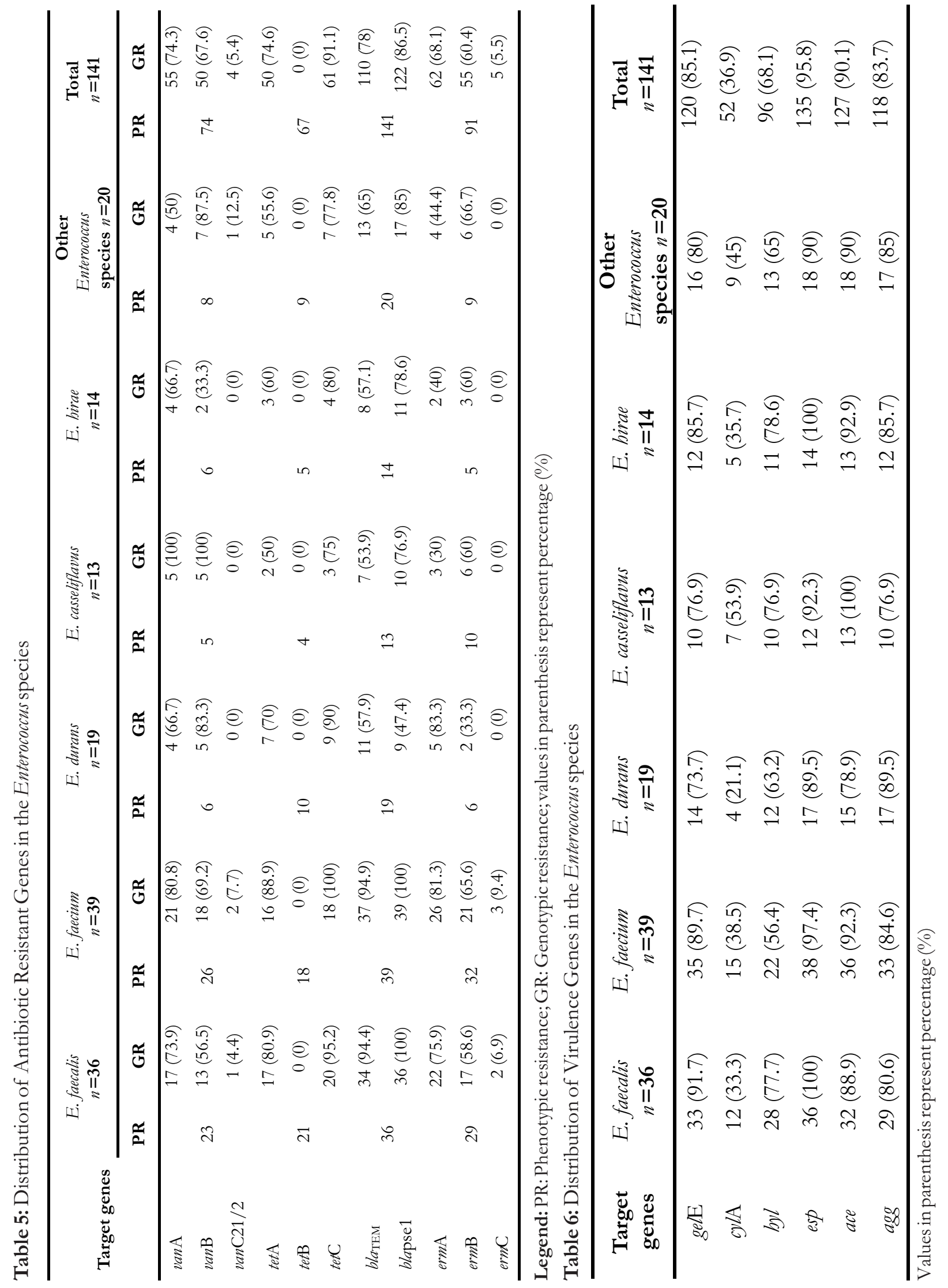


Biofilm formation capacity of the enterococci isolates as shown in table 7 demonstrated nonproducers (25 (17.7\%), weak producers (26 $(18.4 \%)$, moderate producers $(35(24.8 \%)$ and strong producers $(55(39.0 \%)$.

Antibiotic resistant Enterococcus species with biofilm formation potential as shown in table 8 revealed penicillin + biofilm (116 (82.3\%), chloramphenicol + biofilm (116 (82.3\%), clindamycin + biofilm (108 (76.6\%), erythromycin + biofilm $(85(60.3 \%)$, streptomycin + biofilm (99 (70.2\%), vancomycin + biofilm (74 $(52.3 \%)$, imipenem + biofilm (55 (39.0\%), meropenem + biofilm (42 (29.8\%), ciprofloxacin + biofilm (34 (24.1\%), kanamycin + biofilm (40 $(28.4 \%)$ and piperacillin + biofilm $(22(15.6 \%)$.

Table 7: Distribution of Biofilm Formation among the Enterococcus species

\begin{tabular}{lccccccc}
\hline $\begin{array}{l}\text { Biofilm } \\
\text { Indicators }\end{array}$ & $\begin{array}{c}\text { E. faecalis } \\
n=\mathbf{3 6}\end{array}$ & $\begin{array}{c}\text { E. } \\
\text { faec ium } \\
n=\mathbf{3 9}\end{array}$ & $\begin{array}{c}\text { E. } \\
\text { durans } \\
n=\mathbf{1 9}\end{array}$ & $\begin{array}{c}\text { E. } \\
\text { casseliflavus } \\
n=\mathbf{1 3}\end{array}$ & $\begin{array}{c}\text { E. hirae } \\
n=\mathbf{1 4}\end{array}$ & $\begin{array}{c}\text { Other } \\
\text { Enterococcus } \\
\text { species } n=\mathbf{2 0}\end{array}$ & $\begin{array}{c}\text { Total } \\
n=141\end{array}$ \\
\hline $\begin{array}{l}\text { Non } \\
\text { producers }\end{array}$ & $0(0)$ & $7(17.9)$ & $8(42.1)$ & $0(0)$ & $1(7.1)$ & $9(45)$ & $25(17.7)$ \\
$\begin{array}{l}\text { Weak } \\
\text { producers }\end{array}$ & $2(5.5)$ & $5(12.8)$ & $7(36.8)$ & $4(30.8)$ & $5(35.7)$ & $3(15)$ & $26(18.4)$ \\
$\begin{array}{l}\text { Moderate } \\
\text { producers }\end{array}$ & $8(22.2)$ & $13(33.3)$ & $3(15.8)$ & $3(23.1)$ & $5(35.7)$ & $3(15)$ & $35(24.8)$ \\
$\begin{array}{l}\text { Strong } \\
\text { producers }\end{array}$ & $26(72.2)$ & $14(35.9)$ & $1(5.3)$ & $6(46.2)$ & $3(21.4)$ & $5(25)$ & $55(39.0)$ \\
\hline
\end{tabular}

Values in parenthesis represent percentage $(\%)$

Table 8: Antibiotic Resistant Enterococcus species with Biofilm Formation Potential

\begin{tabular}{|c|c|c|c|c|c|c|}
\hline \multirow[t]{2}{*}{ Antibiotics } & \multirow{2}{*}{$\begin{array}{l}\text { Resistant } \\
\text { strains } \\
n=141(\%)\end{array}$} & \multicolumn{4}{|c|}{$\begin{array}{l}\text { Resistant strains with biofilm formation potential } \\
\qquad n=141(\%)\end{array}$} & \multirow{2}{*}{$\begin{array}{c}\text { Total biofilm } \\
\text { producers with } \\
\text { antimicrobial potential } \\
n=141(\%)\end{array}$} \\
\hline & & $\begin{array}{c}\text { Non } \\
\text { producers } \\
n=25(\%)\end{array}$ & $\begin{array}{c}\text { Weak } \\
\text { producers } \\
n=26(\%)\end{array}$ & $\begin{array}{c}\text { Moderate } \\
\text { producers } \\
n=35(\%)\end{array}$ & $\begin{array}{c}\text { Strong } \\
\text { producers } \\
n=55(\%)\end{array}$ & \\
\hline VAN & $74(52)$ & $0(0)$ & $2(7.6)$ & $17(48.6)$ & $55(100)$ & $74(52.3)$ \\
\hline TET & $67(47)$ & $5(20)$ & $4(15.4)$ & $15(42.9)$ & $43(78.2)$ & $62(43.9)$ \\
\hline CIP & $34(24)$ & $0(0)$ & $4(15.4)$ & $3(8.6)$ & $27(49.1)$ & $34(24.1)$ \\
\hline MEM & $42(29)$ & $0(0)$ & $2(7.6)$ & 8 (22.9) & $32(58.2)$ & $42(29.8)$ \\
\hline IMI & $59(41)$ & $4(16)$ & $6(23.1)$ & $10(28.6)$ & $39(70.9)$ & $55(39.0)$ \\
\hline CLI & 131 (93) & $23(92)$ & $18(69.2)$ & $35(100)$ & $55(100)$ & 108 (76.6) \\
\hline KAN & $42(29)$ & $2(8)$ & $0(0)$ & $2(5.7)$ & $37(67.3)$ & $40(28.4)$ \\
\hline STR & $104(73)$ & $5(20)$ & $9(34.6)$ & $35(100)$ & $55(100)$ & $99(70.2)$ \\
\hline ERY & $91(64)$ & $6(24)$ & $3(11.5)$ & $30(85.7)$ & $52(94.5)$ & $85(60.3)$ \\
\hline CHL & $141(100)$ & $25(100)$ & $26(100)$ & $35(100)$ & $55(100)$ & $116(82.3)$ \\
\hline PIP & $29(20)$ & $7(28)$ & $2(7.6)$ & $5(14.3)$ & $15(27.3)$ & $22(15.6)$ \\
\hline PEN & $141(100)$ & $25(100)$ & $26(100)$ & $35(100)$ & $55(100)$ & $116(82.3)$ \\
\hline
\end{tabular}

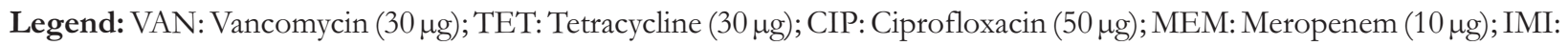
Imipenem $(10 \mu \mathrm{g})$, CLI: Clindamycin $(2 \mu \mathrm{g})$, KAN: Kanamycin $(30 \mu \mathrm{g})$; STR: Streptomycin $(10 \mu \mathrm{g})$; ERY: Erythromycin $(15$ $\mu \mathrm{g})$; CHL: Chloramphenicol $(30 \mu \mathrm{g})$, PEN: Penicillin G $(10 \mu \mathrm{g})$, and PIP: Piperacillin $(100 \mu \mathrm{g})$. Values in parenthesis represent percentage $(\%)$

\section{DISCUSSION}

The capacity to acquire resistance to several classes of antimicrobials constitutes a significant feature of Enterococcus species. This does not only indicate serious therapeutic implication but also creates an environmental reservoir of antimicrobial resistance and virulence genes, often associated with mobile genetic elements, such as plasmids and conjugative transposons (Igbinosa and Beshiru, 2019). In the present study, we characterized the biofilm formation, antimicrobial resistance and virulence of Enterococcus species 
recovered from aquaculture and slaughterhouse environments. The distribution of Enterococcus species in this study revealed Enterococcus faecalis (E. faecalis), E. faecium, E. durans, E. casseliflavus, E. hirae and other Enterococcus species.

Studies from previous authors have also reported similar Enterococcus species from environmental sources (Sadowy and Luczkiewicz, 2014). More than $50 \%$ of the enterococci isolates by Ndubuisi et al. (2017) were resistant to doxycycline and erythromycin which is in agreement with the findings in this study. In addition, antimicrobial susceptibility testing by Sadowy and Luczkiewicz (2014) revealed the resistance to tetracycline, erythromycin, aminoglycosides, ampicillin and fluoroquinolones, similar to the multidrug resistance profile of isolates in this study. All isolates in this study were resistant to penicillin G. In addition, $78 \%$ and $86.5 \%$ of the isolates in this study harboured the $b l_{\mathrm{TEM}}$ and blapse1 genes respectively.

High-level resistance to â-lactam in Enterococcus species is principally attributed to two mechanisms: an assembly of the enzyme âlactamases or the assembly of low-affinity penicillin-binding protein 5 (PBP5) (Arias et al., 2010). Continuous production of PBP5 with reduced-affinity covalently binding to â-lactams is attributed to $E$. faecium but infrequent among $E$. faecalis. Beta-lactamases production is rare in enterococci and can result in high-level resistance via cleavage of â-lactams prior to their target site (cell wall).

Glycopeptides (teicoplanin and vancomycin), are active agents of the cell wall with antibacterial effect by covalently binding with elevated affinity to D-Ala-D-Ala terminal of the precursors of pentapeptide to prevent the peptidoglycan synthesis (Walsh, 2000). Eight variations of acquired glycopeptide resistance $(\operatorname{van} \mathrm{N}$, $\operatorname{van} \mathrm{M}$, $\operatorname{van} \mathrm{L}, \operatorname{van} \mathrm{G}, \operatorname{van} \mathrm{E}, \operatorname{van} \mathrm{D}, \operatorname{van} \mathrm{B}$, and $\operatorname{van} \mathrm{A})$ in enterococci have been described (O'Driscoll and Crank, 2015). The vanA gene is responsible for most human vancomycin-resistant enterococci (VRE) cases globally, mostly expressed by E. faecium (O'Driscoll and Crank, 2015). Bhardwaj et al. (2016) reported that chlorhexidine induces the expression of vanA-type vancomycin resistance genes as well as genes connected with the resistance of daptomycin. Multiple antibioticresistant enterococci in the population represent a threat to human safety. Enterococci easily acquire resistance when exposed to antibiotics or when they acquire genetic resistance factors from neighbouring organisms (Beshiru et al., 2017).

In a study by Heidari et al. (2017), asa1 gene was the most frequently detected gene (100\%) among the isolates, followed by gelE (80.4\%), cylA $(64.7 \%)$, and $\operatorname{byl}(51 \%)$ which was higher than the virulence determinants detected in this study. Extracellular surface protein (esp) is a virulence factor that contributes to biofilm formation and resistance to environmental stresses (Chajecka-Wierzchowska et al., 2017; Igbinosa and Beshiru, 2019). It encourages colonization, adhesion and evasion of the immune system with a crucial role in antibiotic resistance. Kafil and Mobarez (2015) reported a significant correlation between esp harbouring $E$. faecium and vancomycin resistance; while E. faecalis was reported to correlate with esp harbouring enterococci and resistance to tetracycline, chloramphenicol and ampicillin respectively. Studies on the genetics of acquisition and dissemination of resistance and virulence genes, suggests that genetic resistance and virulence can spread through the population via human, environmental or animal reservoirs (Deshpande et al., 2015).

Resistance to erythromycin in Enterococcus species is by methylation of the $23 \mathrm{~S}$ rRNA enzymes methylase encrypted by erm genes and other elements involved the macrolides, lincosamides and streptogramins (MLS) bacterial resistance (Giguère, 2013). MLS bacterial resistance is encrypted by the prevalent erm B determinant and occasionally through erm $\mathrm{C}$ or ermA. Erythromycin resistance methylases (erm) in bacteria express resistance through modification of A2058 nucleotide of $23 \mathrm{~S}$ rRNA (methylation), leading to resistance in MLS antibiotics. The erm B genetic element is distributed among enterococci, particularly E. faecium and E. faecalis (Jensen et al., 1999). The erm B genetic element form part of multi-resistance plasmids often linked with Tn1546-like vanA elements (Laverde-Gomez et al., 2010). 
In strains of E. faecalis, substantive virulence determinants have been elucidated which may adhere to host cells and colonize the mucosal surfaces resulting in infection (Aslam et al., 2012). Such colonization and interactions are referred to as preliminary steps in triggering pathogenesis in many infectious agents. The ace gene (adhesion of the collagen gene) encodes a protein that mediates the connection of bacteria to protein matrix of host cells (Chajecka-Wierzchowska et al., 2017). The esp gene (enterococcal surface protein gene) encodes a surface protein involved in pathogenesis through adhesion characteristics of enterococcal cells to abiotic and biotic surfaces and formation of biofilm. The gelatinase $(\mathrm{ge} / \mathrm{E})$ is a metalloproteinase found in endocarditis and contributes to virulence (Aslam et al., 2012).

A considerable prevalence of genotypic virulence elements ( $g e l \mathrm{E}$, esp and ace) was observed in a good number of the isolates in this study; in agreement with findings from previous studies (Aslam et al., 2012). A significantly positive correlation exists between the beta-haemolytic activity of the Enterococcus species and cylA gene detected in this study $(p<0.05)$. The surface layer (S-layer) form an integral part of the cell envelope that exists in most bacteria. It is made up of a monomolecular coating composed of identical glycoproteins or proteins (Igbinosa and Beshiru, 2019). In many species of bacteria, the S-layer is the sole component of the cell wall and, thus important for osmotic and mechanical stabilization (Igbinosa and Beshiru, 2019).

A significant positive correlation was observed in this study between S-layer, ace, esp and $g e l \mathrm{E}$ genes $(p<0.05)$. Enterococci can infect humans and food animals due to their virulence determinants associated with the formation of biofilm including aggregation substance, gelatinase, enterococcal surface protein and capsule formation (Chajecka-Wierzchowska et al., 2017). E. faecalis has been described by ChajeckaWierzchowska and co-worker as the most common cause of $80-90 \%$ of infection followed by E. faecium with $10-15 \%$ of infection (ChajeckaWierzchowska et al., 2017). The emergence of enterococci with multidrug resistance coupled with the formation of biofilm to vancomycin is predominantly seen in E. faecium (Borhani et al.,
2014). Many strains have been reported to be resistant to one or more antibiotics, including vancomycin (£uczkiewicz et al., 2010). Sadowy and Luczkiewicz (2014) reported that their isolates not only carried several resistance determinants but were also enriched in genes encoding pathogenicity adherent factor (esp) which is in line with the findings in this study. To strategically minimize the threat to human health from antibiotic resistance, understanding its drivers and mechanisms is essential.

\section{CONCLUSION}

The present study has revealed the diversity of Enterococcus species from slaughterhouse and aquaculture effluents in Benin City, Nigeria. In addition, the genetic variability of the enterococcal isolates was characterized. Findings from this study revealed that pathogenic enterococci which inhabit non-human reservoirs could play a key role in the spread and acquisition of antibiotic resistance elements. Since humans play a significant role in the aquaculture and slaughterhouse environments to meet the food demand of the ever-increasing populations, it is necessary to control the discharge of untreated effluents from aquaculture and slaughterhouse to the surrounding environments so as to control the dissemination of antibiotic-resistant bacteria clones in the environment. There is a need for environmental risks communiqué to stakeholders on proper environmental management and the administration of antimicrobial agents and or/ biocides.

\section{CONFLICT OF INTEREST STATEMENT}

The authors have no conflict of interest to declare.

\section{REFERENCES}

Arias, C.A., Contreras, G.A. and Murray, B.E. (2010) Management of multidrugresistant enterococcal infections. Clinical Microbiology and Infection, 16(6): 555-562.

Aslam, M., Diarra, M.S., Checkley, S., Bohaychuk, V. and Masson, L. ( (2) $\left.\begin{array}{llll}0 & 1 & 2\end{array}\right)$ Characterization of antimicrobial resistance and virulence genes in Enterococcus spp. isolated from retail meats in Alberta, Canada. International Journal of Food Microbiology, 156:222-230.

Beshiru, A., Igbinosa, I.H., Omeje, F.I., Ogofure, 
A.G., Eyong, M.M. and Igbinosa, E.O. (2017) Multi-antibiotic resistant and putative virulence gene signatures in Enterococcus species isolated from pig farms environment. Microbial Pathogenesis, 104: 90-96.

Beshiru, A. and Igbinosa, E.O. (2018) Characterization of extracellular virulence properties and biofilmformation capacity of Vibrio species recovered from ready-to-eat (RTE) shrimps. Microbial Pathogenesis 119: 93-102.

Bhardwaj, P., Ziegler, E., Adams, H. and Palmer, K.L. (2016) Chlorhexidine induces vanAtype vancomycin resistance genes in enterococci. Antimicrobial Agents and Chemotherapy, 60: 2209-2221.

Borhani, K., Ahmadi, A., Rahimi, F., Pourshafi, M.R. and Talebi, M. (2014) Determination of vancomycin-resistant Enterococcus faecium diversity in Tehran sewage using plasmid profile, biochemical fingerprinting and antibiotic resistance. Jundishapur Journal of Microbiology, 7(2): 8951-8958.

Cattoir, V. and Leclercq, R. (2013) Twenty-five years of shared life with vancomycinresistant enterococci: is it time to divorce? Journal of Antimicrobial Chemotherapy, 68(4): 731-742.

Chajecka-Wierzchowska, W., Zadernowska, A. and £aniewska-Trokenheim, L. (2016) Diversity of antibiotic resistance genes in Enterococcus strains isolated from ready-toeat meat products. Journal of Food Science, 81: M2799-807.

Chajecka-Wierzchowska, W., Zadernowska, A. and £aniewska-Trokenheim, L. (2017) Virulence factors of Enterococcus spp. presented in food. LWT - Food Science and Technology, 75: 670-676.

Clinical and Laboratory Standards Institute (CLSI) (2017) Performance Standards for Antimicrobial Susceptibility Testing M02A12, M07-A10, and M11-A8. 27th Edition; 282pp.

Daniel, D.S., Lee, S.M., Dykes, G.A. and Rahman, S. (2015) Public health risks of multipledrug-resistant Enterococcus spp. in Southeast Asia. Applied and Environmental Microbiology, 81:6090-6097.
Deshpande, L.M., Ashcraft, D.S., Kahn, H.P., Pankey, G., Jones, R.N., Farrell, D.J. and Mendes, R.E. (2015) Detection of a new $c f r$-like gene, $c f r(\mathrm{~B})$, in Enterococcus faecium isolates recovered from human specimens in the United States as part of the SENTRY antimicrobial surveillance program. Antimicrobial Agents and Chemotherapy, 59: 6256-6261.

Elhani, D., Klibi, N. and Dziri, R. (2014) vanAcontaining E. faecium isolates of clonal complex CC17 in clinical and environmental samples in a Tunisian hospital. Diagnostic Microbiology and Infectious Disease, 79: 60-63.

Food and Agriculture Organization (FAO) of the United Nations (2012) Proceedings of the International Workshop on the Use of Antimicrobials in Livestock Production and Antimicrobial Resistance in the AsiaPacific Region 2012. Food and Agriculture Organization of the United Nations, Rome, Italy.

Frieri, M., Kumar, K. and Boutin, A. (2017) Antibiotic resistance. Journal of Infection and Public Health, 10: 369-378.

Giguère, S. (2103) Lincosamides, Pleuromutilins, and Streptogramins, In Giguère, S., Prescott, J.F., Dowling, P.M. (Eds.) Antimicrobial Therapy in Veterinary Medicine. John Wiley \& Sons, Inc, Oxford, UK, 199-231.

Heidari, H., Hasanpour, S., Ebrahim-Saraie, H.S. and Motamedifar, M. (2017) High Incidence of virulence factors among clinical Enterococcus faecalis isolates in South-Western Iran. Journal of Infection and Chemotherapy, 49(1): 51-56.

Igbinosa, E.O. and Beshiru, A. (2019) Antimicrobial resistance, virulence determinants, and biofilm formation of Enterococcus species from ready-to-eat seafood. Frontiers in Microbiology, 10: 728.

Jensen, L.B., Frimodt-Moller, N. and Aarestrup, F.M. (1999) Presence of erm gene classes in Gram-positive bacteria of animal and human origin in Denmark. FEMS Microbiology Letters, 170: 151-158.

Kafil, H.S. and Mobarez, A.M. (2015) Spread of enterococcal surface protein in antibiotic resistant Enterococcus faecium and 
Enterococcus faecalis isolates from urinary tract infections. Open Microbiology Journal, 9: 14-17.

Kang, C.I. and Song, J.H. (2013) Antimicrobial resistance in Asia: Current epidemiology and clinical implications. Infection and Chemotherapy, 45: 22-31.

Laverde-Gomez, J.A., Van, S.W., Freitas, A.R., Coque, T.M., Weaver, K.E., Francia, M.V., Witte, W. and Werner, G.A. (2010) A multi-resistance mega-plasmid pLG1 bearing a byl(Efm) genomic island in hospital Enterococcus faecium isolates. International Journal of Medical Microbiology, 23: 345-352.

£uczkiewicz, A., Jankowska, K., Fudala-Ksiazek, S. and Olanczuk-Neyman, K. (2010) Antimicrobial resistance of fecal indicators in municipal wastewater treatment plant. Water Research, 44: 50895097.

Marshall, B.M. and Levy, S.B. (2011) Food animals and antimicrobials: Impacts on human health. Clinical Microbiology Reviews, 24: 718733.

Ndubuisi, J.C., Olonitola, O.S., Olayinka, A.T., Jatau, E.D. and Iregbu, K.C. (2017) Prevalence and antibiotics susceptibility profile of Enterococcus spp. isolated from some Hospitals in Abuja, Nigeria. African Journal of Clinical and Experimental
Microbiology, 18(3):154-158.

O'Driscoll, T. and Crank, C.W. (2015) Vancomycin-resistant enterococcal infections: epidemiology, clinical manifestations, and optimal management. Infection Drug Resistance, 8: 217-230.

Rathnayake, I.U., Hargreaves, M. and Huygens, F. (2012) Antibiotic resistance and virulence traits in clinical and environmental Enterococcus faecalis and Enterococcus faecium isolates. Systematic and Applied Microbiology, 35: 326-333.

Sadowy, E. and Luczkiewicz, A. (2014) Drugresistant and hospital-associated Enterococcus faecium from wastewater, riverine estuary and anthropogenically impacted marine catchment basin. BMC Microbiology, 14: 66-681.

Staley, C., Dunny, G.M. and Sadowsky, M.J. (2014) Environmental and animal-associated enterococci. Advances in Applied Microbiology, 87: 147-186.

von Wintersdorff, C.J., Penders, J., van Niekerk, J.M., Mills, N.D., Majumder, S. and van Alphen, L.B. (2016) Dissemination of antimicrobial resistance in microbial ecosystems through horizontal gene transfer. Frontiers in Microbiology, 7:173.

Walsh, C. (2000) Molecular mechanisms that confer antibacterial drug resistance. Nature, 406: 775-781. 